\title{
PENGARUH PEMBELAJARAN OPEN ENDED TERHADAP KREATIVITAS MATEMATIKA SISWA PADA KELAS VIII UNGGULAN MTsN 1 MAKASSAR
}

\author{
Mutmainah \\ Program Studi Pendidikan Matematika, STKIP Bima \\ e-mail:dhara_ina@yahoo.com
}

Abstrak. Penelitian ini bertujuan untuk : 1) Mendeskripsikan kreativitas matematika siswa pada kelas VIII unggulan MTsN 1 Makassar sebelum dan setelah mengikuti pembelajaran Open Ended, 2) mengetahui pengaruh kreativitas matematika siswa diajar dengan pembelajaran Open Ended. Metode penelitian menggunakan Pre-Experiment dengan desain One Group PretestPostest. Populasi dalam penelitian ini adalah siswa kelas VIII unggulan MTsN 1 Makassar tahun ajaran 2016/2017 yang berjumlah 39 siswa dengan teknik pengambilan sampel adalah teknik total sampling. Instrumen yang digunakan adalah tes kreativitas matematika. Teknik analisis data yang digunakan adalah analisis data kuantitatif. Hasil penelitian ini menunjukkan bahwa (1) kreativitas matematika siswa sebelum diajar dengan pembelajaran Open Ended berada pada kategori rendah, dan setelah diajar dengan pembelajaran -Open Ended berada pada kategori tinggi. (2) pembelajaran Open Ended berpengaruh pada kreativitas matematika siswa kelas VIII unggulan MTsN 1 Makassar baik pada rata-rata posttest kreativitas matematika maupun rata-rata peningkatan kreativitas matematika.

Kata Kunci: Open Ended, kreativitas matematika.

Abstract. The research aims: 1) to describe Mathematics creativities of student in class VIII unggulan at MTsN 1 makassar before and after following Open Ended Learning, 2) to discover the influence of mathematics creativities of student who were taught by using Open Ended Learning. Methods the research uses pre experimental desaign with one group pre test-post test. The population of the research were the students in class VIII unggulan at MTsN 1 makassar of academic year 2016/2017 with the total of 39 students. The samples were taken by using total sampling technique. The instruments used is a test of the creativity of mathematics. The data analysis employed quantitative data analysis. The results of the research reveal that (1) Mathematics creativities of students before being taught by using Open Ended Learning are in low category and after being taught by using Open Ended Learning are in high category, (2) Open Ended Learning give influence on Mathematics of students whether for the average of posttest of Mathematics creativities or the average of improvement of Mathematics creativities.

\section{Keywords: Open Ended Learning, Mathematics creativity}

\section{PENDAHULUAN}

Penerapan kurikulum 2013 memerlukan perubahan paradigma pembelajaran, yang dalam prosesnya ada upaya membentuk peserta didik yang berkarakter dan memiliki daya saing. Proses pembelajaran yang seharusnya dilakukan adalah pembelajaran berpusat pada siswa, adanya komunikasi interaktif, siswa aktif mencari sendiri, belajar berkelompok, multidisiplin ilmu, berdasarkan kebutuhan siswa, melatih siswa berpikir kritis.
Harapannya, siswa yang belajar dapat mengalami perubahan sikap dan pola pikir, sehingga terbentuklah kemampuan siswa yang kreatif. Kreativitas memungkinkan penemuan-penemuan baru dalam bidang ilmu dan teknologi, serta dalam semua bidang usaha manusia lainnya, terkhusus di dunia pendidikan.

Perlu disadari bahwa selama ini pendidikan formal hanya menekankan perkembangan yang terbatas pada ranah 
kognitif saja. Adapun perkembangan pada ranah afektif (sikap dan perasaan) kurang diperhatikan. Sebagaimana Suyadi (2015) menyatakan bahwa proses pendidikan kita saat ini terlalu mementingkan aspek kognitif dan mengabaikan kreativitas. Terbukti pada pengajaran di sekolah, jarang sekali ada kegiatan yang menuntut pemikiran divergen atau berpikir kreatif sehingga siswa tidak terangsang untuk berpikir, bersikap, dan berperilaku kreatif. Suyadi menambahkan, proses pembelajaran di sekolah lebih mementingkan pencapaian kurikulum daripada penghayatan dalam kurikulum secara imajinatif dan kreatif. Akibatnya, proses pendidikan yang demikian tidak membuka peluang bagi peserta didik untuk berpikir divergen dan non-konvensional. Oleh sebab itu dalam proses pembelajaran diperlukan cara yang mendorong siswa untuk memahami masalah, meningkatkan kemampuan berpikir kreatif siswa dalam menyusun rencana penyelesaian dan melibatkan siswa secara aktif dalam menemukan sendiri penyelesaian masalah, serta mendorong pembelajaran yang berpusat pada siswa dan guru hanya sebagai fasilitator.

Matematika sebagai salah satu mata pelajaran yang diajarkan mulai dari jenjang pendidikan dasar, selain sebagai sumber dari ilmu yang lain juga merupakan sarana berpikir logis, analis, dan sistematis. Sebagai mata pelajaran yang berkaitan dengan konsepkonsep yang abstrak, maka dalam penyajian materi pelajaran, matematika harus dapat disajikan lebih menarik dan sesuai dengan kondisi dan keadaan siswa. Hal ini tentu saja dimaksudkan agar dalam proses pembelajaran siswa lebih aktif dan termotivasi untuk belajar. Untuk itulah perlu adanya model pembelajaran khusus yang diterapkan oleh guru yang mampu mengasah kreativitas atau cara berfikir kreatif siswa.

Untuk meningkatkan kemampuan berpikir kreatif siswa dalam pembelajaran matematika, perlu dilaksanakan pembelajaran yang memberi kesempatan kepada siswa untuk mengembangkan kemampuan berpikir kreatifnya, adalah satunya adalah pembelajaran Open Ended Problem. Menurut
Kurniasih \& Sani (2014), masalah itu bersifat terbuka (Open Ended Problem), yaitu masalah yang memiliki banyak jawaban atau strategi penyelesaian yang mendorong keingintahuan siswa untuk mengidentifikasi strategi-strategi dan solusi-solusi tersebut. Pemilihan dan perumusan permasalahan yang tepat akan dapat memotivasi siswa untuk belajar secara aktif mengembangkan pengetahuannya secara mandiri dan berkelompok. Dengan adanya perbaikan metode dan cara menyajikan materi pelajaran, diharapkan kemampuan berpikir kreatif dan kritis siswa dapat ditingkatkan.

Selain itu untuk lebih meningkatkan kreativitas siswa dalam menyelesaikan permasalahan matematika, pembelajaran Open Ended menjadi suatu hal yang menarik untuk diterapkan. Purwaningsih, T (2016) menyatakan, Pembelajaran open ended memungkinkan siswa mengembangkan pola pikir sesuai dengan minat dan kemampuan masing-masing dalam berbagai penyelesaian dan jawaban yang beragam. Adapun menurut Permanasari, dkk (2013), pembelajaran dengan open ended formulasi masalah yang digunakan adalah masalah terbuka.

Masalah terbuka adalah masalah yang mempunyai banyak solusi atau strategi penyelesaian. Fadillah (2015), menyatakan bahwa suatu masalah terbuka yang dihadapkan pada siswa bukan hanya berorientasi untuk mendapatkan jawaban atau hasil akhir tetapi lebih menekankan pada bagaimana siswa sampai pada suatu jawaban, siswa dapat mengembangkan metode, cara atau pendekatan yang berbeda untuk menyelesaikan masalah. Menurut Munroe, L. (2015) berpendapat bahwa "An open question is set so that students at various levels within the class can solve the problem based on his or her ability, experience and interpretation of the problem given". Yang artinya soal terbuka dibuat agar siswa di berbagai tingkat di dalam kelas dapat memecahkan masalah berdasarkan kemampuan, pengalaman, dan interpretasinya terhadap masalah yang diberikan.

Dalam penelitian ini, penulis akan menerapkan pembelajaran Open Ended yang 
diharapkan dapat mempengaruhi kreativitas matematika siswa.

\section{METODE PENELITIAN}

Penelitian ini menggunakan metode Pre Experimen dengan desain One Group PretestPostest (Sugiyono, 2011). Populasi dalam metode penelitian kuantitatif adalah siswa kelas VIII unggulan MTsN 1 Makassar tahun pelajaran 2016/2017 yang berjumlah 39 siswa dengan teknik pengambilan sampel menggunakan teknik total sampling. Instrumen dalam penelitian adalah instrumen tes kreativitas matematika yang dianalisis menggunakan uji deskriptif dan uji hipotesis.

\section{HASIL DAN PEMBAHASAN}

\section{Hasil Penelitian}

\section{a) Deskripsi Kreativitas Matematika Siswa}

Analisis yang berkaitan dengan kreativitas matematika siswa yang diperoleh menunjukkan bahwa rata-rata kreativitas matematika siswa sebelum diajar dengan pembelajaran Ended (tes awal) adalah 55,77 dengan standar deviasi 12,65. Berdasarkan kategorisasi kreativitas matematika dimana terdapat 39 siswa, 5 siswa (13\%) berada pada tinggi, 7 siswa (18\%) berada pada kategori sedang, 25 siswa (64\%) berada pada kategori rendah, dan 2 siswa (5\%) berada pada kategori sangat rendah, dan tidak ada siswa yang berada pada kategori sangat tinggi. Adapun skor rata-rata kreativitas matematika siswa setelah diajar dengan pembelajaran Open Ended (tes akhir) adalah 89,41 dengan standar deviasi 6,94. Berdasarkan kategorisasi kreativitas matematika dimana terdapat 39 siswa, 20 siswa $(51 \%)$ berada pada kategori sangat tinggi, dan 19 siswa (49\%) berada pada kategori tinggi, dan tidak terdapat siswa yang berada pada kategori sedang, rendah, dan sangat rendah.

Selanjutnya, Setelah dilakukan pengolahan data hasil tes kreativitas matematika pada tes awal dan tes akhir diperoleh skor peningkatan rata-ratanya adalah 0,76 dengan standar deviasi 0,14. Berdasarkan klasifikasi peningkatan rata-rata 39 siswa, terdapat 27 siswa $(69 \%)$ berada pada kategori tinggi, 12 siswa $(31 \%)$ berada pada kategori sedang, dan tidak terdapat siswa yang berada pada kategori rendah.

\section{b) Uji Hipotesis}

Berdasarkan hasil uji $t$ dengan menggunakan SPSS 22, ringkasan output hasil pengujian adalah sebagai berikut :

- Pengujian rata-rata kreativitas matematika (postest) setelah diajar dengan pembelajaran Open Ended siswa pada kelas VIII unggulan MTsN 1 Makassar lebih dari 69,9 (kategori sedang).

Berdasarkan hasil analisis rata-rata kreativitas matematika (postest) diperoleh nilai sig. $<0,000$ dengan nilai $\alpha=0,05$ sehingga nilai sig $<\alpha$. Dengan demikian $\mathrm{H}_{0}$ ditolak, ini berarti rata-rata posttest kreativitas matematika siswa setelah diajar dengan pembelajaran Open Ended berpengaruh terhadap kreativitas matematika pada siswa kelas VIII unggulan MTsN 1 Makassar.

- Pengujian rata-rata gain kreativitas matematika siswa yang diajar dengan pembelajaran Open Ended lebih besar 0,29 (kategori sedang).

Berdasarkan hasil analisis data rata-rata gain ternormalisasi diperoleh nilai sig. < 0,000 dengan nilai $\alpha=0,05$ sehingga nilai sig $<\alpha$. Dengan demikian $\mathrm{H}_{0}$ ditolak, ini berarti rata-rata gain ternormalisasi siswa yang diajar dengan pembelajaran Open Ended berpengaruh terhadap kreativitas matematika pada siswa kelas VIII unggulan MTsN 1 Makassar.

\section{Pembahasan}

Pada hasil analisis tes kemampuan awal, kreativitas matematika siswa belum terlihat secara signifikan. Hal tersebut terlihat dari skor rata-rata kreativitas siswa masih berada pada kategori rendah. Dari hasil analisis data kreativitas matematika 39 siswa terdapat tujuh siswa mampu menunjukkan aspek kelancaran dengan memberikan jawaban yang sempurna berdasarkan kriteria penilaian, sembilan siswa sudah nyaris sempurna memberikan alternatif jawaban yang tepat dan hanya sedikit melakukan kesalahan dalam menguraikan jawaban, dan dua puluh tiga siswa banyak 
melakukan kesalahan dalam memberikan jawaban yang benar. Pada aspek fleksibilitas, terdapat dua siswa mampu memberikan alternatif pemecahan masalah tetapi masih melakukan sedikit kesalahan dalam menghasilkan jawaban yang benar, dan tiga puluh tujuh siswa lainnya melakukan kesalahan-kesalahan yang lebih banyak dan variatif dalam menyelesaikan masalah matematika sehingga skor kreativitas matematika untuk masing-masing siswa pada aspek fleksibilitas juga lebih variatif. Adapun pada aspek kebaruan (originality) terdapat satu siswa mampu memberikan jawaban yang berbeda dari biasanya tanpa ada kesalahan sedikitpun, satu siswa lainnya memberikan jawaban berbeda dari biasanya tapi masih ada kesalahan dalam kecil dalam memberikan jawaban, dan delapan siswa tidak mendapatkan skor atau dengan kata lain kemampuan originalitasnya tidak ada disebabkan beberapa hal seperti : 1) siswa memberikan jawaban tetapi tidak sesuai dengan masalah yang diajukan, dan 2) memberikan jawaban yang benar tetapi bukan hasil pekerjaanya (hasil menyontek jawaban temannya).

Selanjutnya, kreativitas matematika yang ditunjukkan pada data hasil analisis tes akhir yang diajar dengan pembelajaran Open Ended adalah sebagai berikut: pada aspek kelancaran terdapat 35 siswa memperoleh skor maksimum dan empat siswa mendapatkan skor sedikit dibawahnya. Itu artinya bahwa siswa sudah lancar dalam menghasilkan minimal 2 jawaban yang benar tanpa ada kesalahan dan hanya sebagian kecil siswa yang melakukan sedikit kesalahan dalam memperoleh alternatif jawaban yang benar. Pada aspek fleksibilitas, siswa mendapatkan skor yang variatif disebabkan siswa masih melakukan kesalahan-kesalahan dalam menghasilkan alternatif pemecahan yang benar untuk mendapatkan jawaban itu. Kesalahan-kesalahan yang dilakukan siswa seperti: hanya menghasilkan 1 alternatif jawaban yang benar, menghasilkan minimal 2 alternatif jawaban yang berbeda namun uraian tidak sesuai dengan masalah. Dari jumlah keseluruhan siswa, terdapat 22 siswa memberikan alternatif jawaban yang benar tanpa ada kesalahan dalam menguraikannya, tiga belas siswa memberikan alternatif jawaban yang benar tetapi masih ada sedikit kesalahan dalam menguraikannya, dan 3 siswa lainya melakukan kesalahan yang lebih dalam menjawab soal.

Pada aspek kebaruan, skor yang diperoleh siswa juga variatif. Hanya terdapat 8 siswa yang memperoleh skor maksimum dimana siswa memberikan jawaban-jawaban yang berbeda dari biasanya tanpa ada kesalahan dan jawaban yang diberikan sesuai dengan masalah. Adapun siswa yang lainnya masih malakukan kesalahan-kesalahan baik kesalahan kecil sampai memberikan jawaban yang tidak relevan dengan masalah.

Berdasarkan penjelasan hasil analisis tersebut di atas, maka dapat disimpulkan bahwa terdapat peningkatan secara signifikan kreativitas matematika siswa setelah diajar dengan pembelajaran Open Ended.

Peningkatan kreativitas matematika siswa diperkuat dangan adanya hasil analisis gain ternormalisasi kreativitas siswa, dimana rata-rata peningkatan hasil analisis gain berada pada 0,76 yang berarti bahwa peningkatan kreativitas siswa sudah mencapai skor gain maksimum yaitu berada pada level tinggi. Oleh karena itu, perlu menjadi pertimbangan khusus untuk menggunakan pembelajaran Open Ended dalam pengajaran sehingga memicu kreativitas matematika siswa.

Pada pengujian hipotesis tentang pengaruh pembelajaran Open Ended terhadap kreativitas matematika, diperoleh hasil analisis data secara inferensial melalui uji one sample t-test menunjukkan hasil perhitungan bahwa angka signifikan kurang dari 0,05 baik pada uji rata-rata posttest kreativitas matematika maupun uji rata-rata gain ternormalisasi . Dengan demikian, disimpulkan bahwa terdapat pengaruh kreativitas matematika siswa yang diajar dengan pembelajaran Open Ended.

Hasil penelitian ini sejalan dengan penelitian Noer (2011), bahwa pembelajaran matematika berbasis masalah Open ended dapat meningkatkan kemampuan berpikir 
kreatif. Hasil penelitian lainnya yang mendukung adalah penelitian yang dilakukan Purwaningsih, dkk (2016) pada kedua model Problem Based Learning dan Open Ended, yang mana siswa dengan kreativitas belajar matematika tinggi, sedang, dan rendah mempunyai prestasi belajar matematika yang sama baiknya

\section{KESIMPULAN}

Berdasarkan hasil penelitian dan pembahasan, maka kesimpulan dalam peneleitian ini adalah sebagai berikut:

1. Kreativitas matematika siswa kelas VIII unggulan MTsN 1 Makassar sebelum diajar dengan pembelajaran Open Ended skor rata-rata 55,77 dengan standar deviasi 12,65 berada pada kategori rendah, dan setelah diajar dengan pembelajaran Open Ended skor rata-rata 89,41 dengan standar deviasi 6,94 berada pada kategori tinggi .

2. Rata-rata posttest kreativitas matematika siswa kelas VIII unggulan MTsN 1 Makassar setelah diajar dengan pembelajaran Open Ended lebih besar dari 69,9 berada pada kategori tinggi dan rata-rata gain ternormalisasi siswa lebih besar dari 0,29 berada pada kategori tinggi. Dengan demikian, pembelajaran Open Ended berpengaruh terhadap kreativitas matematika siswa kelas VIII unggulan MTsN 1 Makassar.

\section{SARAN}

Berdasarkan kesimpulan di atas, maka peneliti menyarankan beberapa hal yang perlu diperhatikan:

1. Bagi guru diharapkan mengimplementasikan pembelajaran matematika dengan pembelajaran Open Ended berdasarkan hasil dan temuan dalam penelitian ini, terutama untuk meningkatkan kreativitas matematika siswa.

2. Bagi siswa, untuk meningkatkan aktivitasnya dalam pembelajaran Open Ended, membiasakan bekerja bersamasama dalam kelompok diskusi, saling menghargai dan memperhatikan pendapat dari anggota dalam kelompoknya.
3. Bagi peneliti perlu melakukan penelitian tentang pembelajaran ini yang menyangkut materi lain dalam matematika dengan mempertimbangkan keterbatasan dalam penelitian ini.

\section{DAFTAR PUSTAKA}

Faradilah. 2015. Pembentukan Karakter Siswa Melalui Pembelajaran Matematika. Jurnal Pendidikan Matematika PARADIKMA, (online) Vol 6 Nomor 2 (http://download.portalgaruda.org/artic le.php?article $=143871 \&$ val $=5571$, Diakses 19 Agustus 2016)

Kurniasih \& Sani. 2014. Sukses Mengimplementasikan Kurikulum 2013: Memahami Berbagai Aspek Dalam Kurikulum 2013. Yogyakarta: Kata Pena.

Munroe, L. (2015). The Open-Ended Approach Framework. European Journal of Educational Research, (online) 4(3), 97-104. (http://www.eujer.com/EU-JER_4_3_97_Munroe.pdf . Diakses 10 Juni 2017).

Noer, S. H. 2011. Kemampuan Berpikir Kreatif Matematis Dan Pembelajaran Matematika Berbasis Masalah OpenEnded. Jurnal Pendidikan Matematika, (online), Vol. 5, No. 1 (http://ejournal.unsri.ac.id/index.php/j pm/article/download/824/237, Diakses 19 Agustus 2016).

Permanasari, V., Sugiarto, B., \& Kurniawati, I. 2013. Efektivitas Pendekatan Pembelajaran Openended Terhadap Kemampuan Berpikir Matematis Siswa Pada Materi Trigonometri Ditinjau Dari Kreativitas Belajar Matematika Siswa. Jurnal Pendidikan Matematika Solusi, (online) Vol.1 No.1(

http://jurnal.fkip.uns.ac.id/index.php/ matematika/article/view/1459, Diakses 19 Agustus 2016).

Purwaningsih, T., Usodo, B., \& Sari S, D. R. 2016. Eksperimentasi Model Pembelajaran Problem-Based Learning (Pbl) Dan Open-Ended Learning (Oel) Dengan Pendekatan 
Saintifik Pada Materi Segi Empat Ditinjau Dari Kreativitas Siswa Kelas Vii Mts Negeri Se-Kabupaten Ngawi Tahun Pelajaran 2014/2015. Jurnal Elektronik Pembelajaran Matematika, (online), Vol.4, No.4. (http://jurnal.fkip.uns.ac.i, Diakses 1 Oktober 2016)

Sani. 2015. Pembelajaran Saintifik Untuk Implementasi Kurikulum 2013. Jakarta: Bumi Aksara.

Sugiyono. 2015. Metode Penelitian Pendidikan pendekatan Kuantitatif, Kualitatif, dan $R \& D$. Bandung : Alfabeta.

Suyadi. 2015. Strategi Pembelajaran Pendidikan Karakter. Bandung: Remaja Rosdakarya Offset. 